\title{
The 894G $>$ T variant in the endothelial nitric oxide synthase gene and spina bifida risk
}

\author{
Ivon J. M. van der Linden · Sandra G. Heil • \\ Martin den Heijer $\cdot$ Henk J. Blom
}

Received: 27 February 2007 / Accepted: 29 March 2007/Published online: 4 May 2007

(C) The Japan Society of Human Genetics and Springer 2007

\begin{abstract}
The $894 \mathrm{G}>\mathrm{T}$ single nucleotide polymorphism (SNP) in the endothelial NOS (NOS3) gene, has recently been associated with embryonic spina bifida risk. In this study, a possible association between the NOS3 894G $>\mathrm{T}$ SNP and spina bifida risk in both mothers and children in a Dutch population was examined using both a case-control design and a transmission disequilibrium test (TDT). Possible interactions between the NOS3 $894 \mathrm{G}>\mathrm{T}$ SNP and the MTHFR 677C $>$ T SNP, elevated plasma homocysteine, and decreased plasma folate concentrations were also studied. The NOS3 894TT genotype did not increase spina bifida risk in mothers or children (OR 1.50, 95\% CI 0.71-3.19 and OR $1.78,95 \%$ CI $0.75-4.25$, respectively). The TDT demonstrated no preferential transmission of the NOS3 894T allele $\left(X^{2}=0.06, P=0.81\right)$. In combination with the MTHFR 677TT genotype or elevated plasma homocysteine
\end{abstract}

I. J. M. van der Linden · S. G. Heil · H. J. Blom

Laboratory of Pediatrics and Neurology,

Radboud University Nijmegen Medical Center,

Nijmegen, The Netherlands

M. den Heijer

Department of Endocrinology,

Radboud University Nijmegen Medical Center,

Nijmegen, The Netherlands

M. den Heijer

Department of Epidemiology and Biostatistics,

Radboud University Nijmegen Medical Center,

Nijmegen, The Netherlands

\section{H. J. Blom (ه)}

Metabolic Unit, PK 1-X-018, Department of Clinical Chemistry,

VU University Medical Center, De Boelelaan 1117,

1081 HV Amsterdam, The Netherlands

e-mail: h.blom@vumc.nl concentrations, the NOS3 894GT/TT genotype increased maternal spina bifida risk (OR 4.52, 95\%CI 1.55-13.22 and OR 3.38, 95\%CI 1.46-7.84, respectively). In our study population, the NOS3 $894 \mathrm{GT} / \mathrm{TT}$ genotype might be a risk factor for having a spina bifida affected child in mothers who already have an impaired homocysteine metabolism.

Keywords NOS3 894G $>\mathrm{T} \cdot$ Spina bifida .

Transmission disequilibrium test

\section{Introduction}

Nitric oxide synthase (NOS) catalyzes the generation of nitric oxide (NO), an important signaling molecule that mediates many of its biological effects by activating the enzyme guanylyl cyclase, thereby increasing cyclic GMP synthesis (Murad 2006). Besides its important role in cardiovascular control, NO has been suggested to play a role in development (Lee and Juchau 1994). NO has been demonstrated to be present in the neural tube of chick embryos at the time of neurulation (Traister et al. 2002) and regulates the balance between mitosis and programmed cell death (Plachta et al. 2003). Other studies show that NO can inhibit methionine synthase (MTR) enzyme activity, thereby interfering with homocysteine remethylation (Danishpajooh et al. 2001) and proper neurulation (Nachmany et al. 2006; Weil et al. 2004).

The $894 \mathrm{G}>\mathrm{T}$ single nucleotide polymorphism (SNP) in the endothelial-derived nitric oxide synthase (NOS3) gene, identified by Hingorani et al. (1999), was shown to be associated with elevated plasma homocysteine levels in nonsmokers with low serum folate concentrations (Brown et al. 2003). More recently, it was demonstrated that the NOS3 894GT genotype is an embryonic risk factor for 
spina bifida (OR 1.63, 95\%CI 1.09-2.42) (Brown et al. 2004).

In this study, we examined the relation between the NOS3 $894 \mathrm{G}>\mathrm{T}$ SNP and spina bifida risk in both mothers and children using a case-control design and a transmission disequilibrium test (TDT). An effect of the NOS3 894G $>$ T SNP on plasma homocysteine or plasma folate concentration was examined as well as possible interactions between the NOS3 $894 \mathrm{G}>\mathrm{T}$ SNP and the MTHFR $677 \mathrm{C}>\mathrm{T}$ SNP, elevated plasma homocysteine, and decreased plasma folate concentrations.

\section{Materials and methods}

\section{Study population}

The study population has been described in detail before (van der Linden et al. 2006). Briefly, the study population was recruited in collaboration with the BOSK and was extended by a group from the Pediatric Neurology Department of the Radboud University Nijmegen Medical Center. The study group included 109 spina bifida patients (61 girls and 48 boys, mean age $16.4 \pm 11.3$ ), their mothers $(n=121$, mean age $42.9 \pm 10.9)$ and fathers $(n=103$, mean age $44.9 \pm 10.2$ ).

The control group consisted of 500 volunteers recruited from a general practice in The Hague (den Heijer et al. 1995). In the present study we only included the 292 women from this control group (mean age $50.6 \pm 13.5$ ). The pediatric control group included 234 children (119 girls and 115 boys, mean age $8.4 \pm 6.4$ ) (van Beynum et al. 1999). The children of secondary school age were healthy volunteers, and the younger children were, for ethical reasons, recruited in a hospital setting. The local medical ethics committee approved the study.

For the present study, DNA of 102 spina bifida patients, 116 mothers, 101 fathers, 265 control women and 211 pediatric controls was available for genotyping.

Biochemical determinations

Plasma total homocysteine concentration was measured in EDTA plasma by HPLC and fluorescence detection, as previously described by te Poele-Pothoff et al. (1995).

Plasma folate concentration was determined using the Dualcount Solid Phase Boil Radio assay (Diagnostic Product Corporation, Los Angeles, CA).

PCR amplification and genotype determination

NOS3 894G $>\mathrm{T}$ genotyping was performed according to Hingorani et al. (1999). Primer annealing took place at a temperature of $58^{\circ} \mathrm{C}$. The PCR product of 206 bp was cut with the restriction enzyme $\mathrm{MboI}$, which cuts the T allele in fragments of 119 and $87 \mathrm{bp}$.

Statistical analyses

Case-control study

Odds ratios (ORs) and their 95\% confidence intervals $(95 \% \mathrm{CI})$ were calculated by means of logistic regression analysis.

The effect of the NOS3 $894 \mathrm{G}>\mathrm{T}$ SNP on plasma homocysteine and plasma folate concentration was studied by means of linear regression analysis. Since the distributions of plasma homocysteine and plasma folate concentrations are positively skewed, these variables were logarithmically transformed prior to linear regression analysis.

Deviation from Hardy-Weinberg equilibrium was calculated to assess the accuracy of the genotyping assay.

The power of the case-control study was calculated using the Genetic Power Calculator (Purcell et al. 2003). All tests were performed using SPSS software package version 12.0.1. Statistical significance was accepted at a two-tailed $P<0.05$ or $95 \% \mathrm{CI}$ of an odds ratio that did not include 1.0.

\section{Transmission disequilibrium test}

The relation between the NOS3 $894 \mathrm{G}>\mathrm{T}$ genotype of the spina bifida patients and spina bifida risk was assessed by evaluating the transmission of alleles from heterozygous parents to their affected offspring using the TDT, a familybased association test (Spielman et al. 1993). The power of the TDT was calculated using the Genetic Power Calculator (Purcell et al. 2003).

\section{Results}

Case-control study

The NOS3 894G>T genotype could be determined in 115 mothers of a spina bifida affected child and in 259 female controls. Genotype distribution did not differ from that expected under Hardy-Weinberg equilibrium $(P=0.83)$, and the power to detect a twofold increase in maternal spina bifida risk was 59\%. Table 1 demonstrates that neither the NOS3 894GT genotype nor the NOS3 894TT genotype increased maternal spina bifida risk relative to the NOS3 894GG genotype. Since the effect of the NOS3 894GT genotype and the NOS3 894TT genotype on spina bifida risk was the same relative to the NOS3 $894 \mathrm{GG}$ genotype, the NOS3 894GT and TT genotypes were 
Table 1 The NOS3 894G $>$ T genotype distribution and unadjusted ORs in mothers of a spina bifida affected child and female controls

\begin{tabular}{llll}
\hline $\begin{array}{l}\text { NOS3 } \\
894 \mathrm{G}>\mathrm{T}\end{array}$ & Mothers $(\%)$ & $\begin{array}{l}\text { Female } \\
\text { controls }(\%)\end{array}$ & OR (95\%CI) \\
\hline GG & $49(42.6)$ & $130(50.2)$ & $1^{\mathrm{a}}$ \\
GT & $53(46.1)$ & $106(40.9)$ & $1.33(0.83-2.11)$ \\
TT & $13(11.3)$ & $23(8.9)$ & $1.50(0.71-3.19)$ \\
\hline
\end{tabular}

${ }^{a}$ Reference group

combined to increase power, which resulted in a nonsignificant $36 \%$ increased risk of having a spina bifida affected child relative to the NOS3 894GG genotype (OR 1.36, 95\%CI 0.87-2.11). The NOS3 894G>T SNP was not associated with plasma homocysteine or plasma folate concentrations in mothers and female controls (data not shown).

In 95 spina bifida patients and 207 pediatric controls, NOS3 894G $>$ T genotyping was performed successfully. The NOS3 894G $>$ T genotype distribution did not differ from that expected under Hardy-Weinberg equilibrium $(P=0.76)$, and the power of the study was $51 \%$. The NOS3 894GT genotype increased spina bifida risk in children whereas the NOS3 894TT genotype did not (Table 2). Combining the NOS3 894GT and 894TT genotypes resulted in a $66 \%$ increase in spina bifida risk relative to the NOS3 894GG genotype (OR 1.66, 95\%CI 1.02-2.72). In the pediatric controls, the NOS3 894GT and 894TT genotypes were associated with increased plasma homocysteine concentrations relative to the NOS3 894GG genotype (14.7\% increase, 95\%CI $4.2-26.2 \%$ and $23.5 \%$ increase, 95\% CI 3.9-46.8\%, respectively). There was no association between the NOS3 $894 \mathrm{G}>\mathrm{T}$ SNP and plasma folate concentration in children (data not shown).

Transmission disequilibrium test

In this study there were 75 complete mother-father-child triads, and the power to detect a twofold increase in spina bifida risk was $32 \%$. In 36 out of 70 informative transmissions $(51.4 \%)$, the NOS3 $894 \mathrm{~T}$ allele was transmitted to the child, which resulted in a $\mathrm{X}^{2}$ of $0.06(P=0.81)$.

Table 2 The NOS3 894G $>$ T genotype distribution and unadjusted ORs in spina bifida patients and pediatric controls

\begin{tabular}{llll}
\hline $\begin{array}{l}\text { NOS3 } \\
894 \mathrm{G}>\mathrm{T}\end{array}$ & SB patients (\%) & $\begin{array}{l}\text { Pediatric } \\
\text { controls }(\%)\end{array}$ & OR (95\%CI) \\
\hline GG & $39(41.1)$ & $111(53.6)$ & $1^{\mathrm{a}}$ \\
GT & $46(48.4)$ & $80(38.6)$ & $1.64(0.98-2.74)$ \\
TT & $10(10.5)$ & $16(7.7)$ & $1.78(0.75-4.25)$ \\
\hline
\end{tabular}

${ }^{\text {a }}$ Reference group
Gene-gene interaction

Data on both the NOS3 $894 \mathrm{G}>\mathrm{T}$ genotype and the MTHFR $677 \mathrm{C}>\mathrm{T}$ genotype were present for 110 mothers of a spina bifida affected child and 259 control women. Since the MTHFR 677CT genotype did not increase spina bifida risk relative to the $M T H F R$ $677 \mathrm{CC}$ genotype, we decided to combine the MTHFR $677 \mathrm{CC}$ and CT genotypes to increase power. In combination with the MTHFR 677TT genotype, the NOS3 894GT/TT genotype increased the risk of having spina bifida affected offspring 4.5 times relative to the NOS3 894GG genotype combined with the MTHFR 677CC/CT genotype (OR 4.52, 95\%CI 1.55-13.22) (Table 3$)$.

In children, there was no interaction between the NOS3 894GT/TT genotype and the MTHFR 677TT genotype (OR 1.23, 95\% CI 0.31-4.91) (data not shown).

Gene-metabolite interactions

Since the MTHFR 677C >T SNP is a genetic determinant of plasma folate and plasma homocysteine concentrations, possible interactions between the NOS3 894G>T SNP and these metabolites were examined in mothers. In combination with decreased plasma folate concentrations ( $<8.52 \mathrm{nmol} / \mathrm{L})$, the NOS3 894GT/TT genotype did not increase maternal spina bifida risk relative to the NOS3 894GG genotype in combination with normal plasma folate concentrations $(\geq 8.52 \mathrm{nmol} / \mathrm{L})$ (OR 1.14 , 95\%CI 0.49 2.67) (data not shown). The risk of having spina bifida affected offspring increased to 3.4-fold when the NOS3 894GT/TT genotype was present in combination with elevated plasma homocysteine concentrations $(\geq 12.56$ $\mu \mathrm{mol} / \mathrm{L})(\mathrm{OR} 3.38,95 \% \mathrm{CI} 1.46-7.84)$ (Table 4).

\section{Discussion}

In this study, the NOS3 894TT genotype did not significantly increase spina bifida risk, and the TDT demonstrated no preferential transmission of the NOS3 894T allele. However, in combination with the MTHFR 677TT genotype or

Table 3 Maternal spina bifida risk for the combination of the NOS3 $894 \mathrm{G}>\mathrm{T}$ SNP and the MTHFR $677 \mathrm{C}>\mathrm{T}$ SNP

\begin{tabular}{|c|c|c|c|c|}
\hline $\begin{array}{l}\text { NOS3 } \\
894 \mathrm{G}>\mathrm{T}\end{array}$ & $\begin{array}{l}\text { MTHFR } \\
677 \mathrm{C}>\mathrm{T}\end{array}$ & Mothers (\%) & $\begin{array}{l}\text { Female } \\
\text { controls }(\%)\end{array}$ & OR $(95 \% \mathrm{CI})$ \\
\hline GG & $\mathrm{CC} / \mathrm{CT}$ & $42(38.2)$ & $114(44.0)$ & $1^{\mathrm{a}}$ \\
\hline GG & $\mathrm{TT}$ & $6(5.5)$ & $16(6.2)$ & $1.02(0.37-2.77)$ \\
\hline GT/TT & $\mathrm{CC} / \mathrm{CT}$ & $52(47.3)$ & $123(47.5)$ & $1.15(0.71-1.85)$ \\
\hline GT/TT & TT & $10(9.1)$ & $6(2.3)$ & $4.52(1.55-13.22)$ \\
\hline
\end{tabular}

${ }^{a}$ Reference group 
Table 4 Maternal spina bifida risk for the combination of the NOS3 894G $>$ T SNP and elevated plasma homocysteine concentration, adjusted for age

\begin{tabular}{lllll}
\hline $\begin{array}{l}\text { NOS3 } \\
894 \mathrm{G}>\mathrm{T}\end{array}$ & $\begin{array}{l}\text { Plasma Hcy } \\
\text { conc }(\mu \mathrm{mol} / \mathrm{L})^{\mathrm{a}}\end{array}$ & $\begin{array}{l}\text { Mothers } \\
(\%)\end{array}$ & $\begin{array}{l}\text { Female } \\
\text { controls }(\%)\end{array}$ & OR (95\%CI) \\
\hline GG & $<12.56$ & $42(36.8)$ & $100(38.6)$ & $1^{\mathrm{b}}$ \\
GG & $\geq 12.56$ & $7(6.1)$ & $30(11.6)$ & $0.66(0.26-1.65)$ \\
GT/TT & $<12.56$ & $47(41.2)$ & $108(41.7)$ & $1.17(0.69-1.96)$ \\
GT/TT & $\geq 12.56$ & $18(15.8)$ & $21(8.1)$ & $3.38(1.46-7.84)$
\end{tabular}

a The 80th percentile of the control plasma homocysteine distribution was used to define elevated plasma homocysteine concentrations

${ }^{b}$ Reference group

elevated plasma homocysteine concentrations, the NOS3 894GT/TT genotype increased maternal spina bifida risk 4.5- and 3.4-fold, respectively.

Using a likelihood ratio test (LRT) for both proband and mother trios, Brown et al. (2004) demonstrated the NOS3 894GT genotype, but not the NOS3 894TT genotype, to be an embryonic risk factor for spina bifida (OR 1.63, 95\% CI 1.09-2.42). Data from our case-control study might be in line with this observation of Brown et al. (2004); however, based on the effect of the heterozygous NOS3 894GT genotype on spina bifida risk, a larger effect of the NOS3 894TT genotype on spina bifida risk would be expected. The observation that the NOS3 894GT genotype increases spina bifida risk and the NOS3 894TT genotype does not could be explained as a chance finding, but could also be the result of lack of power, as also suggested by Brown et al. (2004).

Despite the small numbers on which the analyses are based, the possible interactions between the NOS3 894GT/ TT genotype and the MTHFR 677TT genotype or elevated plasma homocysteine concentrations are interesting and may suggest a role for NOS3 uncoupling or S-nitrosation. The NOS3 894G>T SNP (Glu298Asp) has been suggested to impair NOS3 protein function and/or activity resulting in decreased NO production (Sofowora et al. 2001; Tesauro et al. 2000), although results are contradictory (Fairchild et al. 2001). Elevated homocysteine concentrations have been demonstrated to switch the NOS3 enzyme to an uncoupled state directed to the synthesis of reactive oxygen species (ROS) rather than NO synthesis (Topal et al. 2004). The combination of the NOS3 894GT/TT genotype and elevated plasma homocysteine concentrations may lead to such a decrease in NO levels that neurulation is hampered. NO can also react with homocysteine to form $S$-nitrosothiols, thereby modulating homocysteine availability (Stamler et al. 1993). As previously suggested by our group (Heil et al. 2004), decreased NO levels may result in decreased $S$-nitrosothiol formation, resulting in less capturing of homocysteine into $S$-nitrosoHcy. The subsequent increase in plasma homocysteine concentrations might influence proper neural tube closure, especially when plasma homocysteine concentrations are already high.

The results of our study suggest that the NOS3 $894 \mathrm{G}>\mathrm{T}$ SNP is a spina bifida risk factor in the mother and not in the child. Our results furthermore indicate a role for the homocysteine metabolism in the detrimental effects asserted by the NOS3 $894 \mathrm{G}>\mathrm{T}$ SNP. More studies on the association between the NOS3 $894 \mathrm{G}>\mathrm{T}$ SNP and spina bifida in larger populations are warranted.

Acknowledgements This study was supported by the Prinses Beatrix Fonds, The Netherlands (MAR04-0121), the Dutch Kidney Foundation (C042083) and the NIH (1 R01 NS050249-01A1). Martin den Heijer is supported by The Netherlands Organization for Scientific Research (VENI grant NWO).

\section{References}

Brown KS, Kluijtmans LA, Young IS, Woodside J, Yarnell JW, McMaster D, Murray L, Evans AE, Boreham CA, McNulty H, Strain JJ, Mitchell LE, Whitehead AS (2003) Genetic evidence that nitric oxide modulates homocysteine: the NOS3 894TT genotype is a risk factor for hyperhomocysteinemia. Arterioscler Thromb Vasc Biol 23:1014-1020

Brown KS, Cook M, Hoess K, Whitehead AS, Mitchell LE (2004) Evidence that the risk of spina bifida is influenced by genetic variation at the NOS3 locus. Birth Defects Res Part A Clin Mol Teratol 70:101-106

Danishpajooh IO, Gudi T, Chen Y, Kharitonov VG, Sharma VS, Boss GR (2001) Nitric oxide inhibits methionine synthase activity in vivo and disrupts carbon flow through the folate pathway. $\mathrm{J}$ Biol Chem 276:27296-27303

den Heijer M, Blom HJ, Gerrits WB, Rosendaal FR, Haak HL, Wijermans PW, Bos GM (1995) Is hyperhomocysteinaemia a risk factor for recurrent venous thrombosis? Lancet 345:882-885

Fairchild TA, Fulton D, Fontana JT, Gratton JP, McCabe TJ, Sessa WC (2001) Acidic hydrolysis as a mechanism for the cleavage of the Glu(298)->Asp variant of human endothelial nitric-oxide synthase. J Biol Chem 276:26674-26679

Heil SG, den Heijer M, Van Der Rijt-Pisa BJ, Kluijtmans LA, Blom HJ (2004) The $894 \mathrm{G}>\mathrm{T}$ variant of endothelial nitric oxide synthase (eNOS) increases the risk of recurrent venous thrombosis through interaction with elevated homocysteine levels. J Thromb Haemost 2:750-753

Hingorani AD, Liang CF, Fatibene J, Lyon A, Monteith S, Parsons A, Haydock S, Hopper RV, Stephens NG, O'Shaughnessy KM, Brown MJ (1999) A common variant of the endothelial nitric oxide synthase (Glu298->Asp) is a major risk factor for coronary artery disease in the UK. Circulation 100:1515-1520

Lee QP, Juchau MR (1994) Dysmorphogenic effects of nitric oxide (NO) and NO-synthase inhibition: studies with intra-amniotic injections of sodium nitroprusside and NG-monomethyl-L-arginine. Teratology 49:452-464

Murad F (2006) Shattuck lecture. Nitric oxide and cyclic GMP in cell signaling and drug development. N Engl J Med 355:2003-2011

Nachmany A, Gold V, Tsur A, Arad D, Weil M (2006) Neural tube closure depends on nitric oxide synthase activity. J Neurochem 96:247-253

Plachta N, Traister A, Weil M (2003) Nitric oxide is involved in establishing the balance between cell cycle progression and cell death in the developing neural tube. Exp Cell Res 288:354-362 
Purcell S, Cherny SS, Sham PC (2003) Genetic power calculator: design of linkage and association genetic mapping studies of complex traits. Bioinformatics 19:149-150

Sofowora G, Dishy V, Xie HG, Imamura H, Nishimi Y, Morales CR, Morrow JD, Kim RB, Stein CM, Wood AJ (2001) In-vivo effects of Glu298Asp endothelial nitric oxide synthase polymorphism. Pharmacogenetics 11:809-814

Spielman RS, McGinnis RE, Ewens WJ (1993) Transmission test for linkage disequilibrium: the insulin gene region and insulindependent diabetes mellitus (IDDM). Am J Hum Genet 52:506516

Stamler JS, Osborne JA, Jaraki O, Rabbani LE, Mullins M, Singel D, Loscalzo J (1993) Adverse vascular effects of homocysteine are modulated by endothelium-derived relaxing factor and related oxides of nitrogen. J Clin Invest 91:308-318

te Poele-Pothoff MT, van den Berg M, Franken DG, Boers GH, Jakobs C, de Kroon IF, Eskes TK, Trijbels JM, Blom HJ (1995) Three different methods for the determination of total homocysteine in plasma. Ann Clin Biochem 32:218-220

Tesauro M, Thompson WC, Rogliani P, Qi L, Chaudhary PP, Moss J (2000) Intracellular processing of endothelial nitric oxide synthase isoforms associated with differences in severity of cardiopulmonary diseases: cleavage of proteins with aspartate vs. glutamate at position 298. Proc Natl Acad Sci USA 97:28322835

Topal G, Brunet A, Millanvoye E, Boucher JL, Rendu F, Devynck MA, vid-Dufilho M (2004) Homocysteine induces oxidative stress by uncoupling of NO synthase activity through reduction of tetrahydrobiopterin. Free Radic Biol Med 36:1532-1541

Traister A, Abashidze S, Gold V, Plachta N, Karchovsky E, Patel K, Weil M (2002) Evidence that nitric oxide regulates cell-cycle progression in the developing chick neuroepithelium. Dev Dyn 225:271-276

van Beynum IM, Smeitink JA, den Heijer M, te Poele Pothoff MT, Blom HJ (1999) Hyperhomocysteinemia: a risk factor for ischemic stroke in children. Circulation 99:2070-2072

van der Linden IJ, Den Heijer M, Afman LA, Gellekink H, Vermeulen SH, Kluijtmans LA, Blom HJ (2006) The methionine synthase reductase $66 \mathrm{~A}>\mathrm{G}$ polymorphism is a maternal risk factor for spina bifida. J Mol Med 84:1047-1054

Weil M, Abeles R, Nachmany A, Gold V, Michael E (2004) Folic acid rescues nitric oxide-induced neural tube closure defects. Cell Death Differ 11:361-363 